\title{
Climate Change and its Impact on Land Degradation: Imperative Need to Focus
}

\section{Rajesh Kumar* and Amar Jyoti Das}

Department of Environmental Microbiology, School for Environmental Sciences, Babasaheb Bhimrao Ambedkar (A Central ) University, Iucknow, India

*Corresponding author: Rajesh Kumar, Department of Environmental Microbiology, School for Environmental Sciences, Babasaheb Bhimrao Ambedkar University, Vidya Vihar, Raibareli Road, Lucknow-226 025, India, Tel: +919621329477; E-mail: rajesh4971@yahoo.com

Rec date: Feb 26, 2014, Acc date: Mar 28, 2014, Pub date: Apr 04, 2014

Copyright: $\odot 2014$ Kumar $\mathrm{R}$ et al. This is an open-access article distributed under the terms of the Creative Commons Attribution License, which permits unrestricted use, distribution, and reproduction in any medium, provided the original author and source are credited.

\begin{abstract}
Changes in climate are recognized as one of the major factors responsible for land degradation affecting sustained development. To ensure sustained development, conjunctive efforts based on a sound understanding of the various factors that bestow to land degradation around the world are required. Hence, it is more significant to verbalize climate, an inherent driver of land degradation instead of addressing the consequences of land degradation. The present review furnishes impact of climate change on land degradation.
\end{abstract}

Keywords: Climate change; Land degradation; Sustainable development; Soil quality

\section{Introduction}

Anthropogenic climate change is recognized as one of the major factors contributing to land degradation. Land degradation means reduction in the potential of the land to produce benefits from a particular land use under a specified form of land management and is considered to be one of the major problems of the world in recent times [1,2]. Land degradation encompasses change in chemical, physical and biological property of the soil. Such a change in soil properties alter and reduce the soil ability to sustain a peculiar quality and quantity of plant growth [3]. Soils are also crucial to food security and change in climate has threatened the food security by affecting the soil property [4-8]. Understandings of the effects are required to know how climate and soils interact and to understand changes in soil due to change in climate. At regional, ocean basin and continental scales, numerous long-term changes in climate have been noticed. These admit changes in ocean salinity, far-flung changes in precipitation amounts, changes in Arctic ice and temperatures, changes in wind patterns, change in the intensity of tropical cyclones and changes in heat waves and heavy precipitation. More acute and longer Carbon dioxide $\left(\mathrm{CO}_{2}\right)$ accelerated climate change and desertification stay inextricably associated because of feedbacks between precipitation and land degradation. Water resources are also inextricably associated with climate. Annual ordinary river runoff and water availability are projected to rise by 10-40 percent at high latitudes, in wet tropical areas, at mid-latitudes and in the dry tropics it decreases by 10-30 percent. Land exhibited to degradation as a consequence of poor land management could become infertile as a result of climate change. Land degradation hazards included wind and water erosion, loss of soil carbon, nutrient decline mass movement, soil structure decline, acid sulfate soils and soil acidification. Hence the present review furnishes climate change and its impact on land degradation.

\section{Impact by Wind and Water Erosion}

Wind and water erosion are the most widespread form of degradation. In the arid and semi-arid areas risk of wind erosion is serious. It happens whenever soil is left bare of vegetation as a result of cultivation and overgrazing following overstocking. Wind leads to the removal and deposition of soil particles from the top soil surface by its action. Apart from this, it can ensue extra damage by burying buildings, machinery and land with undesirable soil [9].

Water erosion admits various processes such as splash erosion, rill and gully erosion and sheet erosion [3]. Splash erosion normally starts water erosion and takes place as raindrops fall onto the bare soil surface and break up the surface soil aggregates and splashes particles into the air. Soil particles falling into the abandons between the surface aggregates reduce the amount of rainwater and can pass through into the soil and increasing runoff. Water running above the soil surface has the ability to pick up some of the soil particles released by splash erosion and besides, it also detach particles from the soil surface. This consequence may lead to removal of soil particles from the soil surface reasonably on consistent basis and is known as sheet erosion. Rill and gully erosion occurs when runoff gets concentrated into channels. Rills are small streamlets or head cuts of a size that can be checked by tilling. Gullies erode away large amounts of soil with a huge amount of rain. Gullies are similar as rills but basically larger in size. Normal tilling doesn't easily cease gullies.

\section{Impact of Climate Change on Organic Matter Levels}

Organic matter is one of the significant constituent of soils. It frame soil structure and stability, water and oxygen holding capacity and nutrient storage, hence it furnishes a home ground for numerous soil micro flora and fauna. Organic matter is sensitive to changes in the climate and their decomposition rate increases with increased temperature. Expanding of agriculture and its intensification has decreased the levels of soil organic matter. Majority of this organic matter had been lost as carbon dioxide in the atmosphere and this proves that some intensively cropped land release a substantial amount of greenhouse gases [10]. Increase in plant growth due to increased atmospheric $\mathrm{CO}_{2}$ concentrations demonstrates the high use of organic matter from the soils. Hence with the climatic change organic-matter content of the soil highly affected. 


\section{Acidification}

Acidification is a natural process that usually occurs as a consequence of nitrate leaching in high-rainfall areas [11]. Most countries contain large areas of acidified soils and have become a primary problem for agricultural soils, where land management practices modify and aggravate the process [12]. Increase in extent of acidification depends on both temperature and rainfall, i.e. regulated by climate. Substantial increase in rainfall increases leaching and cause acidification, whereas decline in rainfall reduce intensity and extent of acidification [13]. Sub humid and arid geographical zone soils are influenced by seasonal changes i.e. from leaching conditions to evaporative conditions. Acid sulfate soils are the examples of acidification as they suffer from extreme acidity as a result of the oxidation of pyrite when pyrite-rich parent materials are drained [14].

\section{Impact on Nutrient Levels}

Nutrients are another important constituents of soil and concentration of soil nutrients varies from one geographical region to another. Soil nutrient quantity is often affected by climatic factor. Change in temperature and precipitation could affect soil nutrient levels in numerous manners. Increasing temperatures could act to assert nutrients within the soil because of raised evaporative forces and abbreviate leaching [15]. Downward movement of water in soil leads to loss of soil nutrient; hence movement of water to a great extent affects the soil nutrient level. Moreover, decrease in rainfall may cause upward movements of nutrients and thus leads to Stalinization. In tropical and subtropical countries, loss of soil nutrient is an increasing problem $[16,17]$.

\section{Acid Sulfate Soils}

Acid sulfate soils are natural soils that contain iron sulphides generally in the form of iron pyrite. Two different forms of acid sulphide soils occur in nature. One, in which pyrite remains in reducing environment and another in which pyrite has been oxidized by exposure to air leading to the geological formation of sulphuric acid. Oxidation of metal sulfides to sulfuric acid and liberation of significant quantities of metals in environment is responsible for a major environmental menace in coastal lowlands and mined areas where sulfides are present [18-23]. The climate change has severe impacts on acid sulfate soils and severity has reached to extreme by increase in the frequency and of weather events such as heavy rains and droughts [24]. With climate change, the blushing of acid sulfate materials from soil containing acid sulfate and mine wastes will cause greater increases in concentrations that will be an ever increasing threat to aquatic life [25].

\section{Impact on Soil Structure}

Soil structure is unique property of the soil that have a fundamental effect on the behavior of soils, such as, water holding capacity, nutrient transformations and movement, nutrient leaching, and drainage [26]. Climate change deteriorates the soil structure [27]. Changes to soil structure are hard to quantify because of the influence of land use and management, hence further research is this area is required for better understanding of the effect of climate change on soil structure. Soils containing high clay contents incline to shrink when they are in dry condition, but they swell as they went up once again. This leads to formation of large fissures and cracks. Dry climatic conditions increase the size and frequency of crack formation in soils, particularly in temperate regions [28,29]. Increase in crack with increase in quantity of metals, such as aluminum, iron, manganese, heavy metals is observed in case of acid soils when they are subjected to climatic change [13].

\section{Conclusions}

There is overwhelming evidence which points the consequences of climate change in land degradation. Understanding of the consequence and their effects are urgently required to know how climate and soils interact and to understand changes in soil due to change in climate. Further, contribution of research in this field is needed to developed ability to cope and adapt to climate change, ability to assess how and where weather and climate patterns are likely to change and the ability to predict the continuous fluctuations in risk and vulnerability.

\section{References}

1. Blaikie P, Brookfield H (1987) Land Degradation and Society. London, Methuen.

2. Barrow CJ (1992) World Atlas of Desertification (UNEP). London.

3. Douglas AE (1994) Symbiotic interactions. Oxford University Press, London.

4. Pimentel D (2006) Soil erosion: A food and environmental threat. Environ Dev Sustain 8: 119-137.

5. Lal $\mathrm{R}$ (2010) Managing soils and ecosystems for mitigating anthropogenic carbon emissions and advancing global food security. BioScience 60: 708-721.

6. Blum WEH, Nortcliff S (2013) Soils and Food Security. In Soils and Human Health; Brevik EC, Burgess LC Edn CRC Press USA 299-321.

7. Brevik EC (2013) Soils and Human Health-An Overview. In Soils and Human Health; Brevik EC, Burgess LC Edn CRC Press USA 29-56.

8. Brevik EC (2013) Climate Change, Soils, and Human Health. In Soils and Human Health; Brevik EC, Burgess LC Edn CRC Press USA 345-383.

9. Andrien M (1994) Social communication in nutrition: a methodology for intervention.

10. Tate KR (1992) Assessment, based on a climosequence of soils in tussock grasslands, of soil carbon storage and release in response to global warming. J Soil Sci 43: 697-707.

11. Fenton G, Helyar K (2007) Soil acidification. In Soils: Their properties and management, Charman PEV, Murphy BW 3rd edition Oxford University Press Melbourne.

12. Charman PEV, Murphy BW (2007) Soils: Their properties and management. Oxford University Press Melbourne.

13. Wild A (1993) Soils and the Environment. Cambridge University Press, Cambridge, UK.

14. Rounsevell MDA, Loveland PJ (1992) An overview of hydrologically controlled soil responses to climate change in temperate regions. SEESOIL 8: 69-78.

15. Dent D (1986) Acid Sulphate Soils: A Baseline For Research and Development. ILRI Publication Netherlands.

16. Bullock P, Henri UK, France LH (1995) Land Degradation and Desertification.

17. Smaling EMA (1990) Two scenarios for the Sub-Sahara: one leads to disaster. Ceres 22: 19-24.

18. Pereira HC (1993) Food production and population growth. Land Use Policy 10: 187-190.

19. Dinelli E, Lucchini F, Fabbri M, Cortecci G (2001) Metal distribution and environmental problems related to sulfide oxidation in the Libiola copper mine area (Ligurian Apennines, Italy). J Geochem Explor 74: 141-152.

20. Lin C, Lin J (2003) Heavy metals in a sulfldic minespoil: Fractions and column leaching. Pedosphere 13: 75-80. 
Citation: Kumar R, Das AJ (2014) Climate Change and its Impact on Land Degradation: Imperative Need to Focus. J Climatol Weather Forecasting 2: 108. doi:10.4172/2332-2594.1000108

Page 3 of 3

21. Lee PK, Kang MJ, Choi SH, Touray JC (2005) Sulfide oxidation and the natural attenuation of arsenic and trace metals in the waste rocks of the abandoned Seobo tungsten mine, Korea. Appl Geochem 20: 1687-1703.

22. Lu W, Ma Y, Lin C (2011) Status of aluminium in environmental compartments contaminated by acidic mine water. J Hazard Mater 189: 700-709.

23. DeNicola DM, Stapleton MG (2002) Impact of acid mine drainage on benthic communities in streams: The relative roles of substratum Vs. aqueous effects. Environ Pollut 119: 303-315.

24. Levings CD, Varela DE, Mehlenbacher NM, Barry KL, Piercey GE, et al (2005) Effect of an acid mine drainage effluent on phytoplankton biomass and primary production at Britannia Beach, Howe Sound, British Columbia. Mar Pollut Bull 50: 1585-1594.
25. Mirza MMQ (2003) Climate change and extreme weather events: Can developing countries adapt? Climate Policy 3: 233-248.

26. Nordstrom DK (2009) Acid rock drainage and climate change. J Geochem Explor 100: 97-104.

27. Lal R (1994) Sustainable land use systems and soil resilience. In: Soil Resilience and Sustainable Land Use: Greenland DJ, Szabolcs I. CAB International, Wallingford, UK.

28. Boden JB, Driscoll RMC (1987) House foundations-a review of the effect of clay soil volume change on design and performance. Municipal Engineer 4: 181-213.

29. Climate Change Impacts Review Group (1991) The Potential Effects of Climate Change in the United Kingdom. Department of the Environment, HMSO, London, UK. 